Egypt. J. Aquat. Biol. \& Fish., Fol. 11, No.4:81-94 (2007) ISSN 1110-6131

\title{
Pesticides residues in environmental components of Nubia Lake, Sudan
}

\author{
Salwa M. Abou EI Ella \\ Channel Maintenance Research Institute, National Water Research Center, \\ Delta Barrage, P.O. Box 13621, Egypt.
}

\begin{abstract}
Field visits were carried out during January 2006 along the north part of I Nubia Lake for collecting samples of fish; water and sediment to ensure the water quality safety before entering Egypt. The results indicated that residues of organochlorine and organoplrosphorus pesticides are present at low concentrations in the water and majority of common species. These residues have apparently originated from the areas of intensive pesticide application in the Gezera and along the White Nile in central Sudan. So, it is essential that continuous monitoring of residues in the environmental components of the whole lake should be conducted.
\end{abstract}

Key words: Pesticides, fish, water, sediment, Nubja Lake.

\section{INTRODUCTION}

Pesticides are divided into many classes, the most important of which are organochlorine and organophosphorus compounds. Organochlorine compounds, i.e hexachlorocyclohexanes (HCHs), DDT and its metabolites, endosulfan and endosulfan sulfate are ubiquitous, persistent, toxic and bioaccumulated in nature. The unique properties of such compounds make them environmentally persistent with a global distribution and they are thus exerting chronic toxic effects on wildlife and humans (Loganthan and Kannan, 1994). Organochlorine pesticides are still used in Sudan. Therefore, they are considered as an important component of the chemical pollutants found in all parts of the global marine environment. They are potentially hazardous to living systems because of their inclination to bioaccumulate in the lipid component of biological species and their resistance to degradation (GESAMP, 1989).

Organophosphorus pesticides, on the other hand, are known to be higtly soluble in water and relatively short lived in the environment, due to their rapid degradation, depending on their formulation, method of application, climate and growing stage of plant. These types of pesticides generally may cause short term problems when present at high concentration.

Organic pesticides enter freshwater systems through a variety of sources, particularly via agricultural runoff. In the Great lakes, direct discharges or spills from manufacturing plants or other industries can also be serious sources. Other sources are domestic and municipal uses of organic pesticides 
and their associated urban runoff. In the last decade, it has become increasingly clear that the atmosphere can be a major source of organic pesticides to the Great Lakes and thus for large lakes and reservoirs else where. The origin of atmospherically - deposited organic pesticides may be far distant from the point of deposition (Allan et al., 1991a, 1991 b).

The agricultural sector in Sudan employs the majority of the work force, with about $65 \%$ of its population making its living through crop growing or animal grazing. In 1995 , a total of US $\$ 30-40$ million was spent on pesticides in Sudan, mainly on cotton. Around $20 \%$ are used for mosquito and public health pest control. The remaining $80 \%$ are used for control of cotton pests and other related crops, besides considerable amounts used for the control of desert locust, birds and rodents and few are used for veterinary purposes. Organochlorine was banned in Sudan in 1981 with the exception of endosulfan. After that, pyrethroids were used to substitute DDT. Heptachlor, aldrin and dieldrin were used to control termites. Toxaphene, as well as a mixture of DDT and toxaphene was used extensively. (Annica valeij et al., 2004).

Over 200 pesticides are registered in Sudan, either as single components or in combination, in about 700 different formulations of varying toxicity. There is no production, formulation and repacking of pesticides in Sudan at present. In 1963, shell chemicals established a formulation plant to produce organochlorides. No regular environmental monitoring for pesticides takes place in Sudan. However, during the period of late 1970 and early 1980, survey studies on pesticide residues in water, soil, biota, food as well as human samples were conducted. DDT and related derivatives were the most common residues encountered. Other substances including heptachlor, chlordane, endosulfan, aldrin, dieldrin and $\mathrm{HCH}$ ( Hexachloro Hexane) were reported . (UNEP, 2002) \& Annica waleij (2004).

Pesticide residues are often scavenged from the water through sorption on the suspended material that deposited on the bottom to become part of the bottom substrate. Consequently, bottom sediments often become reservoirs of pesticides in the environment (Khan, 1977). Miliadis (1994) stated that pesticide residues reach the aquatic environment through direct runoff, leaching, careless disposal of empty containers, equipment washings, etc.

The sediment component of aquatic ecosystems can be an ultimate sink of pesticides. Suspended particulate enter slower moving waters such as large water bodies settle out, and their associated pesticides are added to the sediment component (Chau and Afgan, 1982).

Pesticide residues in various aquatic ecosystems have been studied by several investigators such as Allen Gil et al. (1997), Pandit et al. (2001), Bhattacharya et al. (2003), Bakan and Ariman (2004), and Sankararamakrishnan et al. (2005), and in Egypt by Badawy et al. (1997), Abbassy (2000), Zidan et al. (2002), and Abassy et al. (2003). 
The present study has been conducted to evaluate the pesticide residues in fish, water and sediment along the north part of Nubia Lake.

Sample collection

\section{MATERIAL AND METHODS}

During January 2006, samples of water, sediments and fishes were collected from ten sites distributed as shown in Figure (1) along the north part of Nubia Lake, namely, El Daka - Okma - El Deweshat - Semina - Kagnarty Morshed - Gomaye - Second cataract- Abd el kader - Doghaim and Dabarosa . Numbers of water and sediment samples were collected at studied Zone of Nubia Lake. A total of 50 individual aduit fishes, representing 11 common species were obtained from local fishermen at Nubia Lake.

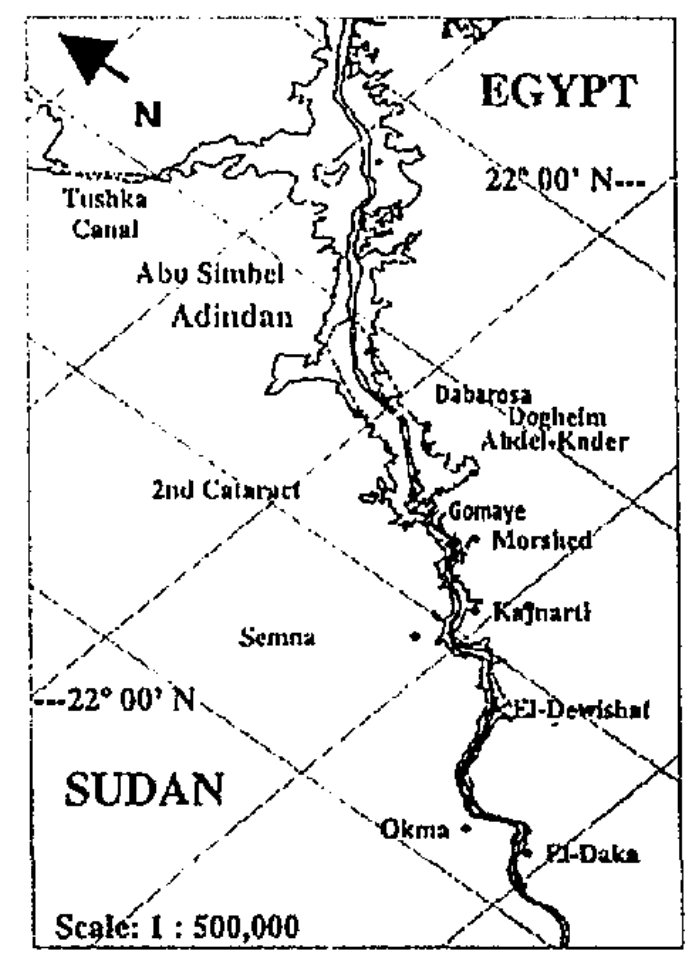

Figure (1): Location map of sites $(\cdot)$ surveyed in Nubia Lake

\section{Analytical procedure}

Water samples were filtered through whatman No. 1 filter paper to remove undissolved and colloid parts, then 1 liter was taken by measuring cylinder and transferred into a 2 liter separatory funnel. Partitioning was carried out three times as 100,50 and $50 \mathrm{ml}$ using dichloromethane (HPLC grade), then extract was dried through $50 \mathrm{~g}$ of anhydrous $\mathrm{Na}_{2} \mathrm{So}_{4}$. The obtained organic phase was evaporated till dryness using rotary evaporator under vacuum at $40^{\circ} \mathrm{C}$. (EPA, 1992).

\section{Sediment samples}

$50 \mathrm{~g}$ of air dried sediment sample were weighed, and homogenized in mortar with $20 \mathrm{~g}$ of anhydrous sodium sulfate. The homogenized samples were 
placed in conical flask then orbital shaker was used for shaking samples for 3 hours with $130 \mathrm{ml}$ mixture of $\mathrm{n}$-hexane and acetone (10: 3 volumes) as modification instead of n-hexane only to be suitable in sediment extraction then was dried through $50 \mathrm{~g}$ of anhydrous $\mathrm{Na}_{2} \mathrm{SO}_{4}$. The obtained organic phase was evaporated till dryness using rotary evaporator under vacuum at $40^{\circ} \mathrm{C}$. (Leyva cardoso et al., 2003).

Fish samples

$10 \mathrm{~g}$ of fish muscles were homogenized with $20 \mathrm{~g}$ of anhydrous sodium sulfate with tissue homogenizer till a fine homogenate was obtained. The homogenate was extracted with $50 \mathrm{ml}$ of $\mathrm{n}$-hexane: acetone (2:1) using HPLC grade. Extraction was carried out using orbital shaker for 2 hours, and then the extract was filtered through anhydrous sodium sulfate and evaporated till dryness, using rotary evaporator under vacuum at $40^{\circ} \mathrm{C}$.

Blank trials for water, sediment and fish samples were carried out to remove any interferring materials coming from solvents used. (Amaraneni and Pillala, 2001).

\section{Cleaning up of sediment and fish samples}

Cleaning up was carried out using $6 \mathrm{~g}$ activated florisi (60-100 mesh) topped with $1 \mathrm{~g}$ anlyydrous $\mathrm{Na}_{2} \mathrm{SO}_{4}$ then column was wet using $30 \mathrm{ml}$-hexane then elution of sample was done with $200 \mathrm{mi}$ of the following mixture dichloromethane : $n$-hexane: acetonitrile (50:48. 5:1.5) (Mills et al., 1972).

\section{Quantitative determination}

Organochlorine pesticide residues were determined by gas chromatograph (Hewlett Packard GC Model 6890) equipped with $\mathrm{Ni}_{63}$ electron capture detector (ECD).

The gas chromatograph condition: DB-17 capillary column (30m length $\times 0.32 \mathrm{~mm}$ internal diameter (i.d.) $\times 0.25 \mathrm{um}$ film thickness). Operating temperatures: column temperature was programmed: initial oven temperature, $160^{\circ} \mathrm{C}$ for $2 \mathrm{~min}$., raised at $3^{\circ} \mathrm{C} / \mathrm{min}$ to $220^{\circ} \mathrm{C}$, then raised $15^{\circ} \mathrm{C}$ to $270^{\circ} \mathrm{C}$ and then held at $240^{\circ} \mathrm{C}$ for $15 \mathrm{~min}$. Injector temperature was $280^{\circ} \mathrm{C}$ and detector temperature $320^{\circ} \mathrm{C}$ with nitrogen carrier gas flow at $4 \mathrm{ml} / \mathrm{min}$. All compounds were identified by their retention times compared to known standards.

The Organochlorine residues components were identified by comparing their retention times with those of the standards quantified by extrapolation of corresponding sample peak areas with those from standard curves prepared for each pesticide standard. Few variations were corrected by obtaining fresh chromatograms of the standard mixture after every nine injections. Standard solutions were prepared for each pesticide of concentrations, ranging from 0.01 to $0.04 \mathrm{ppm}$ and then $1 \mu \mathrm{l}$ was injected into the GC. Peak areas of standard solutions were plotted against their concentrations. A line of best fit was drawn through the points and the limits of detection were taken at five times the detector noise level. 
Organophosphorus pesticide residues were determined by gas chromatograph, (Hewlett Packard GC. Model 6890) equipped witl a flame photometric detector (FPD) with phosphorus filter. A fused silica capillary (DB$1701)$, column containing $14 \%$ cyanopropilsyloxane as stationary phase $(30 \mathrm{~m}$ length $\times 0.32 \mathrm{~mm}$ internal diameter (i.d.) $\times 0.25 \mu \mathrm{m}$ film thickness) was used for the separation in the GC.

The operating conditions of $\mathrm{GC}$ instrument included injector and detector temperature were $250^{\circ} \mathrm{C}$, initial oven temperature $175^{\circ} \mathrm{C}$ for $2 \mathrm{~min}$, raised at $6^{\circ} \mathrm{C} / \mathrm{min}$., and then held at $240^{\circ} \mathrm{C}$ for $15 \mathrm{~min}$, the carrier gas nilrogen at $4 \mathrm{ml} / \mathrm{min}$ and hydrogen and air were used for the combustion at $75^{\circ} \mathrm{C}$ and 10 $\mathrm{ml} / \mathrm{min}$., respectively.

\section{RESULTS AND DISCUSSION}

The distribution of organochlorine and organophosphorus pesticides among fish represented in Tables 1 \& 4, water (Tables $2 \& 5$ ) and sediment (Table $3 \& 6$ ), the samples were collected from ten zones from north part of Nubia Lake.

Table (1): Residue levels of organochlorine pesticides in some Nubia Lake fish specics, January 2006 , nglg.

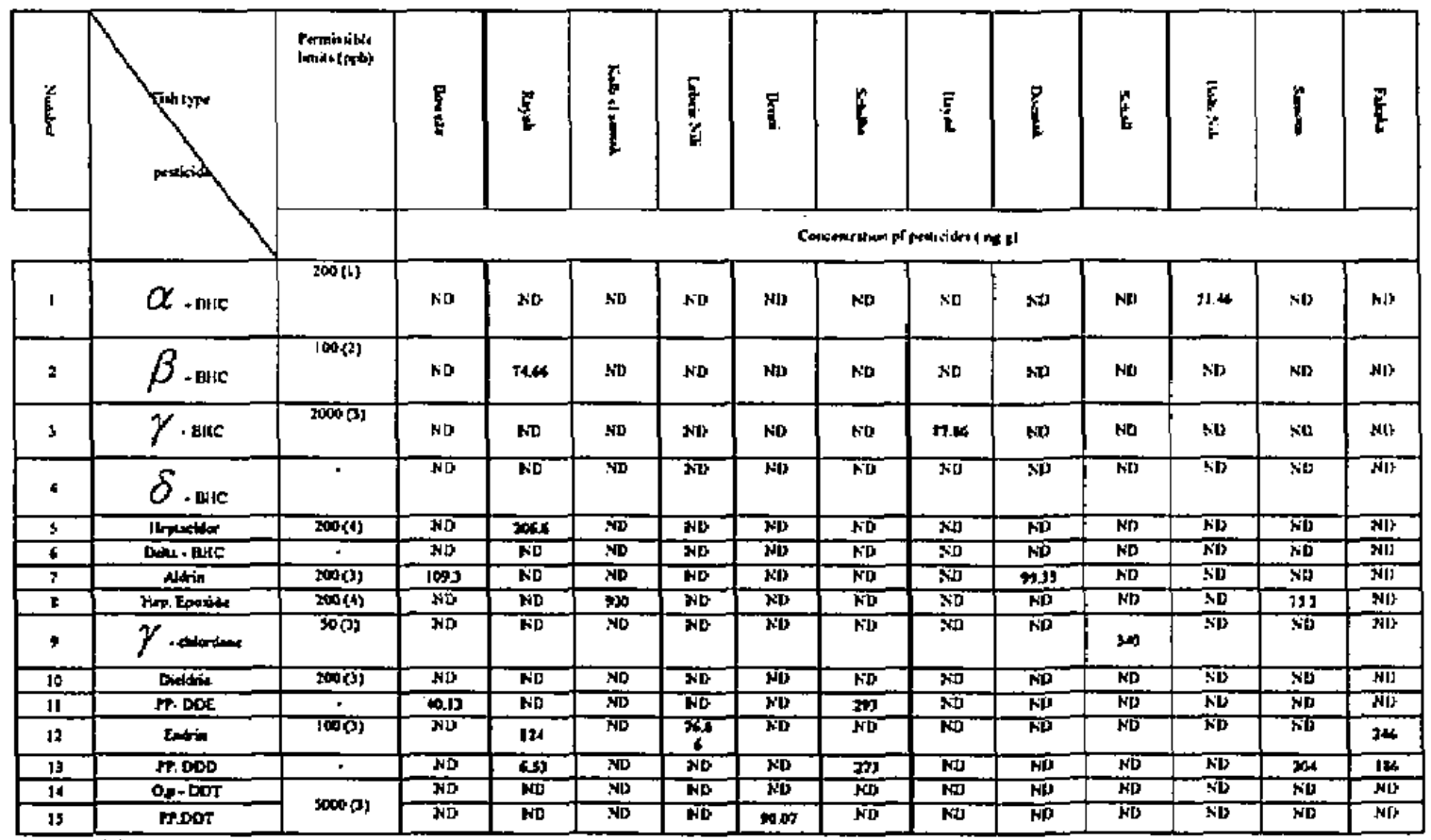

ND: not detectable

(1) FDA (1983)

(2) $\mathrm{FDA}(1994)$

(3) Codex Alimentarius commission, (1999)

(4) Codex Alimentarius commission, (1986)

\section{a- Organochlorine pesticides}


The obtained results revealed that the average levels of the detected organochlorine pesticide residues in the examined freshwater fish muscle samples were 109.3 and $40.13 \mathrm{ng} / \mathrm{g}$ for aldrin and pp.DDE in Boweza (Moryrus casschive); 74.66, 206.6, 124 and 6.53 ng/g for $\beta$-BHC Heptachlor, Endrin and pp. DDD in Raya (Alestes dentex); $930 \mathrm{ng} / \mathrm{g}$ for Hep. Epoxide in kalb el samak (Hydrocynus forskalii); $76.66 \mathrm{ng} / \mathrm{g}$ for endrin in lebeis Nili (Labeo niloticus); $90.07 \mathrm{ng} / \mathrm{g}$ for pp. DDT in Benni (Barbus bynni); 293 and $273 \mathrm{ng} / \mathrm{g}$ for pp.DDE and pp. DDD in schilba (Schilbe (Eutropius) niloticus) $87.86 \mathrm{ng} / \mathrm{g}$ for $\gamma$-BHC in Bayad (Bagrus bajad); $99.33 \mathrm{ng} / \mathrm{g}$ for Aldrin in Docmac (Bagrus docmac); 340 $\mathrm{ng} / \mathrm{g}$ for $\gamma$ chlordane in Schall (Synodontis schall); $21.46 \mathrm{ng} / \mathrm{g}$ for $\alpha-\mathrm{BHC}$ in Bolti Nili (Oreochromis niloticus); 75.2 and $204 \mathrm{ng} / \mathrm{g}$ for Hep. Epoxide and pp.DDD in Samous (Lates niloticus) and 246 and $186 \mathrm{ng} / \mathrm{g}$ for endrin and pp.DDD in Fahaka (Tetraodon linneateus).

El-Zorgani (1980) recorded DDT content of samples of seven fish species taken at Wadi Halfa on Nubia Lake at the border between Sudan and Egypt. The levels of DDT in all fish were significantly higher than the maximum permissible levels. Such high pollution with DDT was attributed to the continued use of DDT on cotton fields in the Gezera project in central Sudan to control agricultural pests and vectors of malaria, typhus, yellow fever and sleeping sickness.

Data in Table (2) indicate the detection of few pesticides in low levels in water samples collected from Nubia Lake. Aldrin, Hep. Eposide, $\boldsymbol{\gamma}$ - Chlordane, pp.DDE, Endrin, pp.DDD, and pp.DDT were detected in the ten locations.

All of the detected pesticides in water samples (Table 2) were at low concentrations, except those collected from Dabarosa section (143 ng/l).

Table (2): Residue levels of organochlorine pesticides in Nubia Lake water, January 2006, ng/l.

\begin{tabular}{|c|c|c|c|c|c|c|c|c|c|c|c|}
\hline 蒒 & Location & $\frac{\text { 를 }}{E}$ & 읕 & $\frac{\underline{n}}{\frac{a}{Z}}$ & 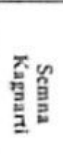 & $\begin{array}{l}3 \\
0 \\
0 \\
2\end{array}$ & مُ & 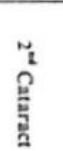 & 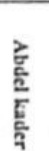 & 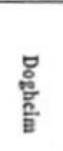 & 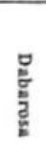 \\
\hline & & \multicolumn{10}{|c|}{ Concentration $p^{\prime}$ pesticides $(n g / g)$} \\
\hline 1 & $\alpha-B H C$ & 49.2 & ND & $\mathrm{ND}$ & ND & ND & $\mathrm{ND}$ & ND & ND & ND & ND \\
\hline 2 & $\beta-B H C$ & 130 & ND & $\mathrm{ND}$ & ND & ND & ND & 355 & ND & ND & ND \\
\hline 3 & $r$ BHC & ND & ND & $\mathrm{ND}$ & ND & ND & ND & ND & ND & ND & ND \\
\hline 4 & 5-BHC & ND & ND & ND & ND & ND & ND & ND & ND & ND & ND \\
\hline 5 & Heptachlor & 209 & 215 & $\mathrm{ND}$ & ND & 147 & ND & ND & ND & 366 & $\mathrm{ND}$ \\
\hline 6 & Delta-BHC & ND & ND & ND & ND & ND & ND & ND & ND & ND & ND \\
\hline 7 & Aldrin & ND & 20.55 & ND & ND & 13 & ND & ND & 25 & 173 & ND \\
\hline 8 & Hep. Epoxide & ND & 35.45 & ND & ND & 107 & ND & ND & 299 & 152 & ND \\
\hline 9 & $\gamma$-chlordane & 145 & ND & ND & ND & 52 & 65.75 & ND & 110 & 30.95 & ND \\
\hline 10 & Dicldrin & ND & ND & ND & ND & ND & ND & ND & ND & ND & ND \\
\hline 11 & PP-DDE & $2 \pi$ & 195 & ND & 33. & ND & ND & 277 & 203 & ND & ND \\
\hline 12 & Endrin & ND & 326 & ND & $\mathrm{ND}$ & ND & ND & ND & ND & ND & 13.6 \\
\hline 13 & PP.DDD & ND & ND & ND & ND & 23,35 & 95 & 1325 & 751 & ND & ND \\
\hline 14 & O.P-DDT & ND & ND & ND & ND & ND & ND & ND & ND & ND & ND \\
\hline 15 & PP-DDT & ND & ND & 330 & 315 & 545 & 509 & 313 & 730 & ND & 311 \\
\hline
\end{tabular}

ND: not detectable

All of the detected pesticides in water samples (Table 2) were at low concentrations, except those collected from Dabarosa section (143 ng/l). 
Among the analyzed organochlorine residues in sediment samples, $\alpha$ BHC, $\beta$-BHC, Heptechlor, Aldrin, Hep. Eposide, $\gamma$-Chlordane, pp-DDF: Endrin, pp.DDD, and PP-DDT were detected at levels ranging from ND to $4 \mathrm{c}: \mathrm{g} / \mathrm{g}$ for $\alpha-\mathrm{BHC}, 130$ to $355 \mathrm{ng} / \mathrm{g}$ for $\beta$-BHC, 147 to $366 \mathrm{ng} / \mathrm{g}$ for Heptachlo. to 25 $\mathrm{ng} / \mathrm{g}$ for Aldrin, 35.45 to $299 \mathrm{ng} / \mathrm{g}$ for Heptachlor, 13 to $25 \mathrm{ng} / \mathrm{g}$ Idrin, 35.45 to $299 \mathrm{ng} / \mathrm{g}$ for Hep.Epoxide, 30.95 to $145 \mathrm{ng} / \mathrm{g}$ for $\gamma$-chlord: .5 to $277 \mathrm{ng} / \mathrm{g}$ for pp. DDE, 15.6 to $32.6 \mathrm{ng} / \mathrm{g}$ for Endrin, 13.25 to 94.5 r pp. DDD and 313 to $730 \mathrm{ng} / \mathrm{g}$ for $\mathrm{pp}$. DDT. The highest concentration $\mathrm{u}$ rved for pp-DDT for several locations in Abdel kader section (730 ng $/$; shed $(545 \mathrm{ng} / \mathrm{g})$, Dabaosa $(511 \mathrm{ng} / \mathrm{g}$ ) and Gomaye $(509 \mathrm{ng} / \mathrm{g})$.

On the contrary, lower levels of organochlorine residues we ined for Aldrin in Morshed section (13 ng/g) and pp-DDE in Okma st $\quad 19.5$ $\mathrm{ng} / \mathrm{g}$ ). Although there is a lack in data concerning Nubia lake sedii, it, the obtained results agree with findings obtained by Sallam et al. (2010) in sediments of River Nile.

As shown in Table (3), the concentration of BHCs was lower than DDTs. This may be due to their differences in physicochemical and biological properties with BHCs, which have higher water solubility, vapor pressure, biodegradability, lower lipophilicity and particle affinity compared to DDTs.

Table (3): Residue levels of organochlorine pesticides in sediment from Nubia l ake, January 2006, ng/g.

\begin{tabular}{|c|c|c|c|c|c|c|c|c|c|c|c|c|}
\hline za & Location & $\begin{array}{l}\text { Drinking water } \\
\text { Euidelelines in } \\
\text { Australia }(\mu \mathrm{B} / 1)\end{array}$ & $\frac{m}{\square}$ & 官 & $\begin{array}{l}\text { 总 } \\
\frac{1}{2} \\
\text { E. }\end{array}$ & 焉然 & 沜 & คิ & 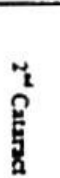 & $\frac{\frac{z}{2}}{\frac{2}{6}}$ & 趈. & 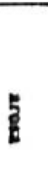 \\
\hline & & & \multicolumn{10}{|c|}{ Concentration of pesticides (nefi) } \\
\hline 1 & $\alpha-$ внс & - & ND & ND & ND & ND & ND & ND & ND & ND & ND & ND \\
\hline 2 & B-BHC & $\cdot$ & ND & ND & ND & ND & ND & ND & ND & ND & ND & ND \\
\hline 3 & $r$-BHC & - & ND & ND & ND & ND & ND & ND & ND & ND & ND & ND \\
\hline 4 & $8-\mathrm{BHC}$ & $\cdot$ & ND & ND & ND & ND & ND & ND & ND & ND & ND & ND \\
\hline 5 & Heptachlor & 0.05 & ND & ND & ND & ND & ND & ND & ND & ND & ND & ND \\
\hline 6 & Delu - BHC & - & ND & ND & ND & ND. & ND & ND & $\pi / 2$ & ND & ND & ND \\
\hline 7 & Addrin & 0.01 & ND & 338. & ND & ND & 72. & ND & ND & ND & 209 & ND \\
\hline 8 & Hep. Epaxide & $\cdot$ & ND & ND & ND & ND & ND & ND & ND & ND & ND & (3) \\
\hline 9 & $y \cdot$ ctilordane & 0.01 & ND & ND & ND & 305 & ND & ND & ND & ND & ND & ND \\
\hline 10 & Dieldrin & - & ND & ND & ND & ND & ND & ND & ND & ND & ND & ND \\
\hline 11 & PP-DDE & . & 1835: & ND & ND & ND & ND & ND & ND & ND & ND & ND \\
\hline 12 & Endrin & - & (5) & ND & ND & ND & ND & ND & ND & ND & ND & ND \\
\hline 13 & PP.DDD & $\cdot$ & ND & 25 & ND & ND & ND & ND & 128 & ND & ND & ND \\
\hline 14 & O.P.DDT & \multirow{2}{*}{0.06} & ND & ND & ND & ND & ND & ND & ND & ND & ND & ND \\
\hline 15 & $P P=D D T$ & & ND & ND & (2) & ND & ND & ND & ND & ND & ND & ND \\
\hline
\end{tabular}




\section{b- Organophosphorus pesticide}

Concentrations of organophosphorus pesticides in Nubia Lake are shown in Tables (4), (5), and (6). Compounds identified included ethoprophos, diazinon, Chlorpyriphos methyl, chlorpyriphos, malathion, fenitrothion, fenthion, fenthioate, and profenophos.

In fish, bioconcentration from water via the gills, skin, and food is a possible route for organophosphorus (OP) pesticide to accumulate in tissue: the route depends mainly on their feeding preference, general behavior, and trophic level (Fisher, 1995). The present study indicated that Samous species (Lates niloticus) has a higher tendency to bioaccmulate OP than others, which can be attributed to its specific feeding habits.

Table (4): Residue levels of organophosphorus pesticides in some Nubia Lake fish species, January 2006, ng/g.

\begin{tabular}{|c|c|c|c|c|c|c|c|c|c|c|c|c|c|c|}
\hline 菆 & & $\begin{array}{c}\text { Permissi } \\
\text { ble } \\
\text { limits } \\
\text { (pmb) }\end{array}$ & 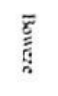 & $\begin{array}{l}\text { 胥 } \\
\text { 总 }\end{array}$ & 揞 & $\begin{array}{l}\bar{E} \\
\bar{c} \\
\underline{a} \\
z \\
\underline{E}\end{array}$ & $\overline{\underline{t}}$ & $\frac{6}{E}$ & $\frac{\tilde{E}}{\tilde{E}}$ & 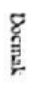 & $\frac{\underline{K}}{\underline{\underline{t}}}$ & $\begin{array}{l}\frac{g}{E} \\
\frac{E}{E} \\
\underline{Z z}\end{array}$ & $\frac{\tilde{E}}{\tilde{E}}$ & $\frac{\bar{p}}{\frac{\vec{p}}{5}}$ \\
\hline & & & \multicolumn{12}{|c|}{ Concentration of pesticides $(\mathrm{n} / \mathrm{g})$} \\
\hline 1 & ethoptophios & $\cdot$ & NiI) & NII) & ND & SiD & ND & ND & (II) & ND & ND & BiD & ND & $\mathrm{NDD}$ \\
\hline 2 & condusaphios & $\cdot$ & FiD & (iI) & ND & (N1) & NiD & NDI & ND & ND & N(I) & ND & ND & NII) \\
\hline 3 & phorate & $\cdot$ & ND & (ii) & BiI) & ND & NID & ND & NID & ND & ND) & ND & ND & NII) \\
\hline 4 & dincition & $700(1)$ & Ni) & (ii) & BND & ND & MID & NI) & ND & ND & NII) & ND & NII) & ND \\
\hline 3 & $\begin{array}{l}\text { Chlorpynphos } \\
\text { methyt }\end{array}$ & so(1) & 83.28 & 159.15 & BiI) & ND) & RD & AD & NDI & NID & NI) & ND & NII) & 103 \\
\hline 6 & chiomstriptos & $2(x)(1)$ & ND) & (ii) & NiI) & ND & NI) & 73.78 & ND & 41.5 & 83.12 & NID & ND & Ni) \\
\hline 7 & imalatheon & $\cdot$ & ND & III) & Ni) & ND & (II) & (ii) & NI) & ND & NI) & NII) & 300 & N(1) \\
\hline 8 & Fenituothion & $50(1)$ & NI) & 1000.8 & (N) & ND & 212 & NI) & NiD & ND & BNI) & ND & ND & (ND) \\
\hline 9 & fenthern & $\cdot$ & ND & (NI) & ND) & ND) & ND & NI) & NI) & ND & (Ni) & NID & 126 & 182 \\
\hline (10) & Fenthioate & $\cdot$ & NI) & तil) & 109.6 & $\mathrm{ND}$ & ND & ND) & NI) & NI) & (ii) & 45.2 & NI) & N(I) \\
\hline II & Profenopios & $50(1)$ & (i.I) & ND & ND & 98.93 & ND & ND & 91.1 & ND & ND & NI) & 360 & ND \\
\hline 12 & fonamighos &. & NI) & SD & N(I) & $\mathrm{ND}$ & (7) & ND & ND & ND & Ni) & NI) & ND & ND \\
\hline
\end{tabular}

ND: not detectable

(1) Codex Alimentarius commission, (1999)

Tables (5) and (6) illustrate OP concentration in water and sediments samples for ten sampling sites. The level of concentrations were 20.8 and 37.06 $\mathrm{ng} / \mathrm{l}$ for fenthion and profenophes in El-Daka section, $40.76 \mathrm{ng} / \mathrm{l}$ for profenophos in Semna and Kagnarti section, 44.9 and $17.6 \mathrm{ng} / \mathrm{l}$ for chlorpyriphos methly and fenthion in Gomaye section; $23.85 \mathrm{ng} / \mathrm{l}$ for fenthioate in Abdel kader section and $99.82 \mathrm{ng} / \mathrm{l}$ for dazinon in Dabarosa section.

Table (5): Residue levels of organophosphorus pesticides in Nubia Lake water, January 2006, ng/l.

\begin{tabular}{|c|c|c|c|c|c|c|c|c|c|c|c|c|}
\hline 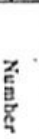 & Location & $\begin{array}{c}\text { Drinking } \\
\text { water } \\
\text { guidelines } \\
\text { in } \\
\text { Australia } \\
(\mu \rho /)\end{array}$ & $\begin{array}{l}\frac{1}{0} \\
\frac{\pi}{6}\end{array}$ & 웉 & 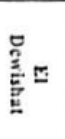 & 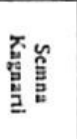 & 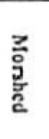 & 尽 & : & 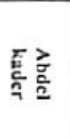 & 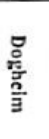 & 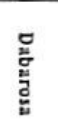 \\
\hline & & & \multicolumn{10}{|c|}{ Concentration pf pesticides (ng/) } \\
\hline 1 & Ethoprophios & $I$ & ND & ND & ND & ND & ND & ND & ND & ND & ND & ND \\
\hline 2 & Cadusiphos & - & ND & ND & ND & ND & ND & ND & ND & ND & ND & ND \\
\hline 3 & Phiorate & $\cdot$ & ND & ND & ND & ND & ND & ND & ND & ND & ND & ND \\
\hline 4 & Diarinon & 1 & ND & ND & ND & ND & ND & ND & ND & ND & ND & 39.82 \\
\hline 5 & $\begin{array}{l}\text { Chlorpytiphos } \\
\text { methyl }\end{array}$ & $\cdot$ & ND & ND & ND & ND & ND & 44,9 & ND & ND & ND & ND \\
\hline 6 & Chlorpiriphos & - & ND & ND & ND & ND & ND & ND & ND & ND & ND & ND \\
\hline 7 & Malathion & $\cdot$ & ND & ND & ND & ND & ND & ND & ND & ND & ND & ND \\
\hline 8 & Fenitrothion & . & ND & ND & ND & ND & ND & ND & ND & ND & ND & ND \\
\hline 9 & Fenthion & $\cdot$ & 20,8 & ND & ND & ND & ND & 17.6 & ND & ND & ND & ND \\
\hline 10 & Fenthioatc & - & ND & ND & ND & ND & ND & ND & ND & 23,85 & ND & ND \\
\hline II & Profenophos & 0.3 & 3706 & ND & ND & $\$ 0.76$ & ND & ND & ND & ND & ND & ND \\
\hline 12 & Feramiptios & - & ND & ND & ND & ND & ND & ND & ND & ND & ND & ND \\
\hline
\end{tabular}

ND: not detectable 
Residues of OP in sediments are given in Table (6). It is evident that the concentrations of studied compounds were subject to considerable variation with respect to sites. The concentration values were 106.6 and $36.3 \mathrm{ng} / \mathrm{s}$. for fenitrothion and fenthioate in El-Daka section, $58.6 \mathrm{ng} . \mathrm{g}$ for chlorpy .... methyl in El-Dewishat section, $153 \mathrm{ng} / \mathrm{g}$ for chlorpyriphos methyl in $2^{\text {nd }}$ cal at and $13.59 \mathrm{ng} / \mathrm{g}$ for Ethoprophos in Dabarosa section. Our findings : in harmony with that obtained by Sallam (2006).

Table (6): Residue levels of organophosphorus pesticides in sediment from Nubia Lake. $2006, \mathrm{ng} / \mathrm{g}$.

ND: not detectable

\begin{tabular}{|c|c|c|c|c|c|c|c|c|c|c|c|}
\hline$\frac{Z}{\sum_{i}}$ & Location & $\frac{\bar{z}}{\frac{2}{2}}$ & $\widehat{\underline{\underline{z}}}$ & 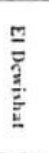 & 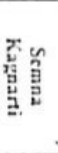 & 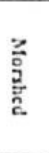 & 吕 & 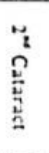 & $\begin{array}{l}\text { 를 } \\
\text { 总总 }\end{array}$ & i & \\
\hline & & \multicolumn{10}{|c|}{ Concentrittion po pesticides (ng/g) } \\
\hline 1 & Elloptophos & ND & $\mathrm{ND}$ & ND & ND & ND) & NII) & ND) & ND & ND) & $135 \%$ \\
\hline 2 & Cadusaplios & SD & SD & ND & ND & ND & ND & ND & ND & N1) & ND \\
\hline 3 & Phoratc & SD & SD & ND & ND & ND & ND & ND & ND & NI) & ND \\
\hline 4 & Diarinon & SD & SD & ND & ND & ND & ND & ND & NI) & ND & ND \\
\hline 5 & Chlorpyriphos methyl & SD & SD & 58.6 & ND & ND & ND & 153 & ND & NiI) & ND \\
\hline 6 & Chlorps riphios & א & $\mathrm{ND}$ & ND & ND & ND & ND & ND & ND & Ni) & No \\
\hline 7 & Malathion & SD & ND & ND & ND & ND & ND & ND & ND & ND & $\mathrm{ND}$ \\
\hline 8 & Fenitrothion & 106.6 & $\mathrm{ND}$ & ND & ND & ND & ND & ND & ND & ND & ND \\
\hline 9 & Fenthion & $\mathrm{ND}$ & $\mathrm{ND}$ & ND & ND & ND & ND & ND & ND & ND & ND \\
\hline 10 & Fenthioate & 36.3 & $\mathrm{SD}$ & ND & ND & ND & ND & ND & ND & ND & ND \\
\hline II & Profenoplios & $\mathrm{ND}$ & SD & ND & ND & ND & ND & ND & ND & ND & ND \\
\hline 12 & Fenamiphos & ND & $S D$ & ND & ND & ND & ND & ND & ND & ND & ND \\
\hline
\end{tabular}

The presence of chlorpyrifos methyl, fenitrothion and fenthioate, in sediments samples collected from Nubia Lake could be attributed to the intense agricultural activity in the area. On the other hand, the absence of most organophosphorus pesticides in water and sediment may be attributed to its rapid degradation, depending on their formulation, rate of application, method of application and climatic factors. These compounds are highly soluble in water and relatively short-lived in the environment

From the results, Nubia Lake shows that the residues of organochlorine and organophosphorus pesticides exist in low concentrations in water and majority of common species. These residues have apparently originated from the areas of intensive pesticide application in the Gezera and along the White Nile in central Sudan. The natural processes of weathering are likely to result in the transfer of pesticide residues to the main course of the Nile, especially during the rainy season and hence their transport downstream. Nubia Lake is the site of deposition for most of the Nile-borne silt and other suspended matter. Under these circumstances, it is expected that an appreciable build-up of residues with time will take place around the agriculture zone in central Sudan. Increased contamination with residues is certain to adversely affect the fish population (E1 Zorgani, 1979) and hence endanger the plants for the development of the fisheries industry in this vital area. In order to keep the situation under control, it is essential that a system for the continuous monitoring of residues as key environmental components in the whole lake should be established. 


\section{Conclusion and Recommendations}

The following can be concluded from this research:

1- Some pesticides with negative carcinogenic effects are still used in Sudan.

2- The collected fjsh samples from Nubia Lake are contaminated with low levels of pesticides.

3- Levels of organochtorine and organophosphorus insecticides in water are still within safety margins, compared to the permissible limits for drinking waters.

4- Continuous monitoring of pesticide residues in freshwater fish is recommended to detect any probable addition of organochlorine pesticide along Nile Basin countries in order to keep the water away from the sources of pollution.

\section{REFERENCES}

Abbassy, M.S.; Ibrahim, H.Z. and Abdel-Kader, H.M. (2003). Persistent organochlorine pollutants in the aquatic ecosystem of Lake Manzalla, Egypt. Bull. Environ. Contam. Toxicol, 70: 1158-1164.

Abbassy, M. S. (2000). Pesticides and polychlorinated biphenyls drained into north coast of the Mediterranean Sea, Egypt. Bull. Environ. Contam. Toxicol. 64: 508-517.

Allen Gil, S.M.; Gubala, C.P.; Wilson, R.; Landers, D.H.; Wade, T.L.; Sericano, J.L.; and Curtis, L.R. (1997) . Organochlorine pesticides and polychlorinated biphenyls (PCBs) in sediments and biota from US Arctic Lakes. Arch Environ. Contam. Toxicol., 33: 378-387.

Allan, R.J.; Ball, A.J.; Cairna, V.; Fox, G.A.; Gilman, A.P.; Peakall, D. B.; Piekarz, D.; Van Oastdam, J.C.; Villeneuve, D.C. and Williams, D.C. (1991a). Toxic chemicals in the Great lakes and Associated Effects. Volume I. Contaminant levels and trends. Pub. Govt. Of canada, $420 \mathrm{pp}$.

Allan, R.J.; Ball, A.J.; Cairna, V.; Fox, G.A.;Gilman, A.P.; Peakall, D. B.; Piekarz, D.; Van Oastdam, J.C.; Villeneuve, D.C. and Williams, D.C. (199lb). Toxic chemicals in the Great lakes and Associated Effects. Volume II. Effects. Pub. Govt. of canda, 210pp.

Amaraneni, S.R. and Pillala, R.R. (2001). Concentrations of pesticide residues in tissues of fish from kolleru lkae in India. Environ. Toxicol., 16:550-556. 
Annica W., Christina E., Martin H.. Birgitta L., Birgitta L., Anders L., Lena M., Magnus N., Bjorn S., Magnus S., Sture S., Kristina S., (2004). Sudan environmental and health risks to personnel to be deployed to Sudan pre-deployment assessment. FOI, Swedish defence Research Agency. Issn, pp.1650-1942.

Badawy, M.I. and Wahaab, R.A. (1997). Environmental impact of some chemical pollutants on Lake Manzala. Int. J. Euviron. Health Res. 7: 161-170.

Bakan, G. and Anman, S. (2004). Persistent of organochlorine residues in sediments along the coast of mid-black sea region of Turkey. Marine Pollution Bull. 48: 1031 - 1039 .

Bhattacharya, B.; Sarkar, S.K.; and Mukherjee, N. (2003). Organochlorine pesticide residues in sediments of a tropical mangrove estuary, India: implications for monitoring. Environ. Internat., 29: 587-592.

Chau, A.S.Y. and Afgan, BK. (1982). Analysis of pesticides in water I, II, III, Boca Raton, FL.C.F.Bakan \& Ariman (2004).

Codex Alimentarius Commission (1986). Guide to codex recommendation concerning pesticide residues. $2^{\text {nd }}$ Ed. Vol. XIII. CAC/PR, $\mathrm{FAO} / \mathrm{WHO}$, Rome, Italy.

Codex Alimentarius Commission (1999). Pesticides in food: Maximum Residue Limits. Extraneous Maimum Residue Limits 2, Sep. 1999.

EPA Report, Official standard methods Manual Guidelines for water, 625/R92/0 04, USEPA (Office of water), Washington Dc.

EI Zorgani, A.M. and Ali, M. E. (1979). Residues of organochlorine insecticides in fishes in Lake Nubia. Bull. Environm. Contam. Toxicol. , 22:044-048.

FDA "Food and Drug Administration" (1983). Limits issued from Canada, FRG, Denmark, Sweden, United States and Thailand. Cited after AlSafy (2000).

FDA "Food and Drug Administration" (1994). Organochlorine contaminants in egg and tissues of wood duck from Mississippi. Bull. Environ. Contam. Toxicol., 45: 870-875. 
FDA "Food and Drug Administration" (1994). Organochlorine contaminarts in egg and tissues of wood duck from Mississippi. Bull. Environ. Contam. Toxicol., 45: 870-875.

Fisher, S.W. (1995). Mechanisms of bioaccumulation in aquatic systems. In: Ware, G.W. (Ed.), Rev. Environ, contam. T.142. Springer, New York, pp. 87-118.

GESAMP (1989). The atmospheric input of trace species to the world ocean. GESAMP, reports and studies, No. 38. C.F. Pandit et. al. (2001).

Khan, M.A. Q. (1977). Pesticides in Aquatic Environment. Plenum Pres, New York. C.F. Bhattacharya, et. al. (2003).

Leyva cardoso,D.O.; Ponce-Velez, G.; Botello, A.V. and Diaz-Gonsalez. (2003). Persistent Organochlorine Pesticides in Coastal Sediments from Petacalco Bay. Guerrero, Mexico. Bll. Environ. Contam. Toxicol., 71:1244-1251.

Loganathan, B.G. and Kannan, K. (1994). Global organochlorine contamination trends; an overview. Ambio, 23: 187-191. C.F. Guzzella, L.; Roscioli, C.; Vihrano, L.; Saha, M.; Sarkar, S.K.; and Bhattacharya, A. (2005). Environ. Int., 31: 532-534.

Milliadis, G.E. (1994). Determination of pesticide residues in natural waters of Greece by solid phase extraction and gas chromatography. Bull. Env. contam. Toxicol., 52: 25-30.

Mills, P.A.; Bong: B.A.; Kamps, L.R. and Burke, J.A. (1972). Elution solvent system for florisil column cleans up in organochlorine pesticide residue analysis. J.A.O.A.C., 55 (1):39-43.

Pandit, G.G.; Mohan, Rao, A.M.; Jha, S.K.; Krishnamoorthy, T.M.; Kale, S.P.; Raghu, K. and Murthy, N.B.K. (2001). Monitoring of organochlorine pesticide residues in the Indan marine environment. Chemosphere, 44: 301-305.

Sankaramakrishnan, N.; Sharma, A.K. and Sanghi, R. (2005). Organochlorine and organophosphorus pesticide residues in ground water and surface water of kanpur, Uttar Pradesh, India. Environ, Int., 31: 113-120. 
UNEP (2002). Regionally Bassed Assessment of Persistent toxic Substances", UNEP Chemicals, Sub-saluaran Africa Regional Report.

Zidan, Z. H.; Gupta, G.; Abdel-Meged, M.l.; Mohamed, K.A. and Bnyoumi, A.E. (2001). Monitoring of pesticide resides and metals water and soil system in industrial and agricultural areas at kalubia governorate, Egypt. The first conf. of the Central Agric. Pesticide Lab, pp.119-138. 